\title{
Bank Credit Risk Rating Process: Is There a Difference Between Developed and Developing Country Banks?
}

\author{
Emna Damak ${ }^{1}$ \\ ${ }^{1}$ Ecole Supérieure des Sciences Economiques et Commerciales, Université de Tunis, Tunisie \\ Correspondence: Emna Damak, Enseignante universitaire à l'Ecole Supérieure des Sciences Economiques et \\ Commerciales, Université de Tunis, Unité de Recherche DEFI, 4 Rue Abou Zakaria El Hafsi, Montfleury 1089, Tunis, \\ Tunisie. Tel: 216-98-589-240.
}

Received: August 12, 2021

Accepted: September 1, 2021

Online Published: December 2, 2021

doi:10.5430/ijfr.v13n1p1

URL: https://doi.org/10.5430/ijfr.v13n1p1

\begin{abstract}
The purpose of this article is to study empirically the bank credit risk rating (BCRR) process across country groups (developed countries 'DdC' against developing countries ' $\mathrm{DgC}$ ') after the 2012 revision of their methodologies as a response to the global and European crisis. We use the S\&P's ratings of 231 banks from 36 EMENA countries which of 18 are developed. We made this comparison based on the CAMELS model with a proposed ' $\mathrm{S}$ ' to BCRR. We perform 'ordered logit' regression for the rating classes and complete our analysis by 'linear multiple' regression for the rating grades. The results show that the entire rating process, including the weight of components, the important factors and the relevant variables, of DdC banks differs partly from this of $\mathrm{DgC}$. The intrinsic credit quality component of the rating has more weight for the allocation of rating grades of DdC banks and the environment supports component has more weight for those of $\mathrm{DgC}$. Some important factors represented by relevant variables are specific to each bank group and others are the same for both groups, but with a difference in the influence on the rating assigned. Sovereign rating has become more relevant to define bank groups than the country level of development.
\end{abstract}

Keywords: bank credit risk rating, credit rating agencies, rating process, CAMELS Model, determinants, European debt crisis

JEL Code: G21, G24, G32

\section{Introduction}

The credit rating agencies (CRA) began to reveal their BCRR methodologies after the 1997 Asian crisis with the publication of a several specific documentations. Then the debate over their inability to properly assess the risk of default grew after the bankruptcy of Enron in 2001, Parmalat in 2003 and the financial crisis of 2007-09 which led, among other things, the bankruptcy of Lehman Brothers. Waves of criticism have been directed at the CRA. In response to these criticisms, as the IMF indicated in 2010, the CRA undertook revisions to BCRR methodologies and revealed them to be more transparent.

The revealed methodologies are the set of qualitative and quantitative criteria, grouped into factors and key analytical factors, developed by agencies in their publications (Gaillard, 2008). And the practiced methodologies are all these criteria integrated and applied in the rating process.

The study of the evolution of BCRR's revealed methodologies by Damak and Chichti (2017) based on the specific publications of the three most world-renowned agencies: S\&P's, Moody's and FitchRatings (S\&P's, 2011c; FitchRatings, 2011a, b; Moody's, 2012c) show, among others, that despite similar rating components and factors and the use of the same information to assign a solicited rating, the CRA use certain BCRR criteria with different weights between groups of banks. The distinction between the groups is based on the level of development of the country or market of the bank's establishment: developed countries - emerging countries (Moody's, 1999 a, b), developed markets - emerging markets (S\&P's, 1998) and mature markets - developing markets (Moody's, 2007a). The authors specify that from 2011, the year of the outbreak of the European debt crisis, one of the consequences of the 2007-09 global crisis (Alogoskoufis, 2012), the CRA in their revisions of the methodologies no longer spoke the level of development. They began to publish specific documents instead speaking of the importance of the relationship between the sovereign 
rating of the country where the bank is located and its BCRR (S\&P's, 2011d; Moody's, 2012b, c, d; FitchRatings, 2011c, 2012). But Damak and Chichti (2017) work was limited to describing the evolution of the revealed methodologies before and after the Asian and the subprime crisis without a thorough econometric study to detect the practiced methodologies.

Damak (2018) conducted a theoretical study followed by empirical validation to adopt the famous CAMELS (Note 1) model by proposing an adjusted ' $\mathrm{S}$ ' to the BCRR and using simple indicators based on quantifiable information available to the public from their financial statements. This adjusted model explicitly incorporates the two components of the BCRR: the intrinsic quality of the credit that generates the 'stand-alone' rating and the environmental support that generates the 'support' rating. And the combination of the two components gives the 'all-in' ratings on the universal scale of long-term ratings. The work empirically validated the adjusted model but did not address the comparison across bank groups.

Several scientific studies have found evidence that the specific variables to the country where the bank is located affect the BCRR but have not shown the difference in the rating process. Considering these findings, assuming that the ratings are consistent with the theoretical micro and macro-economic foundations and that the CAMEL'S' model explain the 'all-in' ratings, we will try through this study to respond to the following question: Is there a difference between the BCRR process of DdC and DgC banks?

Our objective of this work is to complete the perspective of the comparison between the DdC and $\mathrm{DgC}$ bank ratings through the study of practiced methodologies by comparing their rating process from the publicly available information. We are going to investigate the structural breaks across country groups and test the relevance of the country development level in the attribution of BCRR. Our contribution lies in the following two points: (i) the first point is to use the CAMEL'S' model with an adjusted 'S' to compare the rating process of BCRR. Indeed, previous research dealing with a bank group comparison was limited to the use of certain variables without referring to a 'tailor-made' BCRR model. (ii) The second point is that this comparison is processed in 2012 after the completion of the revision of its methodology in response to the global and European debt crisis.

Using the ratings of S\&P's, the agency that made the most significant changes to its revealed methodology, the results showed evidence at two levels. On the one hand, the rating process composites of DdC and $\mathrm{DgC}$ banks differ partly. The intrinsic credit quality (environment supports) component of the rating has more weight for the allocation of ratings of $\mathrm{DdC}(\mathrm{DgC})$ banks than for those of $\mathrm{DgC}(\mathrm{DdC})$. Some important factors represented by relevant variables of the 'all-in' ratings are specific to each bank group and others are the same for both groups, but with a difference in the influence on the 'all-in' rating assigned. On the other hand, sovereign rating after the 2012 methodology revision has become more relevant to define bank groups than the country level of development which is consistent with the revealed methodology.

The rest of this paper is structured as follows: in the second section, we will present a selected empirical and theoretical studies on the comparison of credit risk rating between groups. In the third section, we will present the conceptual framework and our research hypotheses. In the fourth section, we will outline the methodological aspects necessary to test the validity of our hypotheses. In the fifth section, we will analyze the results of the comparison across groups. And in the sixth section, we will finish this work with a conclusion.

\section{The Literature Review}

The scientific literature that we are going to present focuses on the comparison of credit risk rating across country groups. The groups considered are defined according to many criteria: the level of development (DdC against $\mathrm{DgC}$ ), the level of income (middle against high income countries), the membership of a political or economic association (former members of the European Union (EU) against new ones; stronger EU countries against troubled EU countries ; G-20, PIIGS, BRIC, EU or OPEC membership; BRIMITS, shipbuilder or platinum reserved countries), the channels of asymmetric information (economic cycle, countries' economic development, banking supervision, and private monitoring), the continents and/or the regions (United States of America, Europe, Asia, ...).

Most of the authors conducted the analyses either in a global way (without explicit distinction between banks located in the DdC of those in the DgC) (Pasiouras, Gaganis, \& Zopounidis, 2006; Pasiouras, Gaganis, \& Doumpos, 2007; Bellotti, Matousek, \& Stewart, 2011a, b; Caporale, Matousek, \& Stewart, 2011; Orsenigo \& Vercellis, 2013) or by considering sample composed exclusively of DgC banks (Laruccia \& Revoltella, 2000). For example, in modelling the stand-alone ratings of FitchRatings, Caporale et al. (2011) found that country specific factors are crucial determinants for banks in the European Union (EU) countries. And the banks in new EU countries (DgC) have lower ratings than the former countries of this union after the control of financial variables. They implicitly showed that the BCRR in the 
DgC are affected by the factors specific to these countries. Bellotti et al. (2011a, b) also found that the country-specific effects affect the bank's rating. A bank in a less stable, less developed and less wealthy economy seems to have a lower rating.

Several studies, making these comparisons conducted before and/or after the global crisis, in an implicit or explicit manner, have found evidence that the variables specific to the bank's country of location affect the BCRR but have not shown the difference in the rating process. Table 1 summarizes a selection of these works with their key results. We are going to highlight those works as we move forward in the presentation of the sections of this work.

\section{Conceptual Framework and Research Hypothesis}

\subsection{CAMELS Model With a Proposed 'S' for the BCRR}

We are going to use an adaptation of CAMELS model to the BCRR proposed by Damak (2018) which uses a specific ' $\mathrm{S}$ ' and simple indicators drawn from publicly available quantifiable information. This 'over measure' model considers the two components of the BCRR: the intrinsic credit quality measured by the first five factors 'CAMEL' and the environmental support measured by the last factor ' $\mathrm{S}$ '.

$$
\begin{gathered}
\text { Rating 'all-in' }=f(\text { component } 1, \text { component } 2)=f(\text { Intrinsic credit quality, Environment supports }) \\
\text { Rating 'all-in' }=f(C A M E L, \text { Supports })=f(C A M E L ' S ')= \\
f(\text { Capital, Assets, Management, Earnings, Liquidity, Supports })=
\end{gathered}
$$

$f$ (Capital, Assets, Management, Earnings, Liquidity, Sovereign rating, Size, Origin of capital, Activity of the bank)

Given that our work is intended to test the importance of various composites in the rating process with a certain hierarchy [components [factors [variables]]], we use the term 'weight' for the components, 'importance' for factors and the term 'relevance' for variables.

\subsection{Research Hypotheses}

The first work, to our knowledge, which explicitly, but in a modest way, explained the relationship between the BCRR and the variables specific to the country of the bank's establishment by a sample of the DdC and DgC banks is that of Peresetsky and Karminsky (2011). The latter showed that the banks of the $\mathrm{DgC}$ have lower ratings and higher levels of external support than those of the DdC banks and advanced same reasons such as the CRA consideration of political

\begin{tabular}{|c|c|c|}
\hline $\begin{array}{l}\text { Autors/Year/Number of } \\
\text { countries/Country groups }\end{array}$ & $\begin{array}{l}\text { Subject/Sample/Period/ } \\
\text { Methods of analysis }\end{array}$ & Main results \\
\hline $\begin{array}{l}\text { Ferri, Liu, \& Majnoni } \\
\qquad(2001) \\
60 \text { countries } \\
\text { (24 high income countries } \\
\text { 'HIC' and } 36 \text { non-high } \\
\text { income countries 'NHIC') }\end{array}$ & $\begin{array}{l}\text { Examine the potential impact for } \\
\text { NHIC) of linking bank capital asset } \\
\text { requirements (CAR) to private sector } \\
\text { ratings - as contemplated by the new } \\
\text { Basel proposal using the S\&P's data } \\
\text { of } 959 \text { Banks and } 895 \text { Non-banks firms } \\
\text { in } 1999 \text { using OLS panel regression } \\
\text { (random effects). }\end{array}$ & $\begin{array}{l}\text { - They regard sovereign ratings as the "pivot of all } \\
\text { other country's ratings". } \\
\text { - The rating criteria used for companies in NHIC } \\
\text { differ from those in HIC. } \\
\text { - Bank and corporate ratings in NHIC (as opposed } \\
\text { to their homologues in HIC) are strongly linked to } \\
\text { their sovereign ratings. }\end{array}$ \\
\hline $\begin{array}{c}45 \text { countries } \\
\text { (29 Dd and } 16 \mathrm{Dg})\end{array}$ & $\begin{array}{l}\text { Disentangle the relative contribution to } \\
\text { firms' ratings of sovereign risks and of } \\
\text { the individual firms' performance } \\
\text { indicators employed by CRA based en } \\
563 \text { firms ( } 135 \text { from DgC) rated by } \\
\text { S\&P's using OLS estimations adjusted } \\
\text { for heteroskedasticity and 2SLS } \\
\text { estimations. }\end{array}$ & $\begin{array}{l}\text { - The contribution of sovereign risk to firm ratings } \\
\text { is high in } \mathrm{DgC} \text { but is negligible in DdC. } \\
\text { - In DdC, financial ratios can include almost all of } \\
\text { the information content of a company's credit ratings, } \\
\text { while in DgC, ratings are heavily dependent on } \\
\text { sovereign risk and financial ratios play a negligible } \\
\text { role. }\end{array}$ \\
\hline
\end{tabular}
risk in these countries.

Table 1. Selected studies on the comparison of credit risk rating across country groups 
Caporale et al.

(2011)

27 countries of the

European Union (EU)

(15 old and 12 new)

Peresetsky \& Karminsky
(2011)
42 Dd and Dg countries
(Europe, Asia,
Commonwealth of
Independent States (CIS
including Russia) and other
countries excluding North
America)
Shen, Huang \& Hasan
(2012)
86 middle and high income
countries (M\&HIC) of
North America \& West
Europe regions
Orsenigo \& Vercellis
(2013)
40 countries of EU, USA
and Asia

Assess whether 'old' and 'new' EU countries are rated differently using 303 banks (1168 'stand-alone' ratings) of FitchRatings from 1996 to 2008 by employing "ordered probit \& logit" models (heterogeneous effect of countries).

Present an econometric study of the «joint-default analysis 'JDA'» of 1135 'all-in' and 'stand-alone' ratings of Moody's based en 380 banks for the period from 2003 to 2006 using "ordered-logit" and lineaire regressions.
- Country-specific factors are determining for ratings. - CRA determine ratings in a different way for 'old' and 'new' EU countries in terms of the financial position of banks.

- The 'new' members of the EU generally have lower ratings than the 'old' ones.

- Banks in DgC have lower ratings than banks in DdC because of political risk in these countries and banks in DdC avoid publishing low ratings due to the inconveniences that can result. As opposed to their homologues in $\mathrm{DgC}$, where any rating by an international CRA is a good sign.

- Banks in DgC have higher levels of external support than that of banks in DdC.
Investigate why 'all-in' ratings of S\&P's differ among banks with similar financial ratios in different countries using 3347 observations between 2002-2008 with 'Ordered probit' model.

Present an empirical evaluation of the effectiveness of two linear and nonlinear dimensionality reduction techniques for BCRR prediction using 'all-in' ratings of FitchRatings in 2012 of 374 commercial European banks.
- CRA attribute greater weight to bank financial ratios in industrialized or HIC and countries with low information asymmetry.

- CRA attribute a significant weight to capital, even in a country with severe information asymmetry.

- For all regions, the total assets, the net interest margin and the "cost / income" ratio appear relevant. - The other variables were specific to each region. For European banks, the Net profit and the "non-interest expense/average assets" ratio are relevant.

\begin{tabular}{|c|c|c|}
\hline $\begin{array}{l}\text { Teker, Pala \& Kent (2013) } \\
23 \text { countries (13 developed } \\
\text { and } 10 \text { emerging: G-20, } \\
\text { PIGS, BRIC or EU or } \\
\text { OPEC membership, } \\
\text { BRIMITS or shipbuilder } \\
\text { or platinum reserved } \\
\text { countries) }\end{array}$ & $\begin{array}{l}\text { Compose a new sovereign rating } \\
\text { methodology and investigate the } \\
\text { structural breaks in time and cross } \\
\text { section (pre/post subprime crises and } \\
\text { across country groups) using } \\
\text { FitchRatings between 1998-2010 using } \\
\text { FCA and ordered probit model. }\end{array}$ & $\begin{array}{l}\text { - In the aftermath of the } 2008 \text { global financial crisis, } \\
\text { the differentiation of economic indicators between } \\
\text { groups of Dd and Dg countries, following the } \\
\text { implementation of various monetary and fiscal } \\
\text { policies to recover, forced the CRA to modify the } \\
\text { criteria and the weights used in their risk assessment } \\
\text { and to define new structures. }\end{array}$ \\
\hline $\begin{array}{l}24 \text { countries (22 European } \\
\text { countries, USA and Japan) }\end{array}$ & $\begin{array}{l}\text { Analysis of the adjustment of the } \\
\text { 'all-in' ratings of S\&P's, Moody's and } \\
\text { FitchRatings of } 475 \text { banks as a result of } \\
\text { the financial crisis during the period of } \\
2004 \text { to } 2013 \text { using a specific } \\
\text { methodology. }\end{array}$ & $\begin{array}{l}\text { - If the results are disaggregated by geographical } \\
\text { areas (USA, EU, and within these, the PIIGS } \\
\text { countries), the factors which explain the adjustment in } \\
\text { ratings do not have the same relative importance in all } \\
\text { groups of countries. }\end{array}$ \\
\hline $\begin{array}{c}76 \text { countries (from } 5 \\
\text { continents) with different } \\
\text { economic cycles, level of } \\
\text { development, banking } \\
\text { supervision, and private } \\
\text { monitoring. }\end{array}$ & $\begin{array}{l}\text { Examines the "indirect effects" of } \\
\text { credit ratings on banks' capital ratios } \\
\text { with studing whether the associations } \\
\text { between credit ratings and banks' } \\
\text { capital structure can be explained by } \\
\text { the channels of asymmetric information } \\
\text { in the 1998-2013 period using } 391 \\
\text { commercial banks rated by } \\
\text { FitchRatings ( } 4,024 \text { observations) and } \\
\text { the two-step system GMM estimator. }\end{array}$ & $\begin{array}{l}\text { - The effects of negative rating signals vary } \\
\text { significantly with economic cycles. The effects are } \\
\text { significantly negative and pronounced when a } \\
\text { country's economy is in a poor state. However, as the } \\
\text { economy's health improves, the rating effects } \\
\text { decrease to zero and eventually become positive. } \\
\text { - Only the downgrade effect is sensitive to the three } \\
\text { other channels of asymmetric information: countries' } \\
\text { economic development, banking supervision, and } \\
\text { private monitoring. }\end{array}$ \\
\hline
\end{tabular}

Source: This table is the author's construction from the collected studies. 
Shen et al. (2012) have deepened the investigation. These authors showed that the CRA place greater weight on banks' financial ratios, calculated based on financial reports, in industrialized or high-income countries because of the low level of information asymmetry and/or better quality of the institutional and legal environment and/or the good quality of financial statements. On the contrary, the weight of ratios on the rating process is minimal in middle-income countries due to lack of transparency and/or high level of asymmetry of information and/or poor quality of financial statements. Similar results have been found by Ferri et al. (2001) and Ferri \& Liu (2004) with corporate credit ratings.

On the CRA side, Moody's (2007a) stated that it attaches great importance to financial fundamentals in assigning its stand-alone ratings to mature market banks (sovereign ceiling in currency is Aa1 or higher), this is much less true in the case of banks operating in developing markets (sovereign ceiling in currency is less than Aa1). It specifies that for banks operating in mature markets, qualitative and quantitative factors are equally weighted. However, for banks operating in developing markets, it gives more than twice weight to qualitative factors than to quantitative factors. Also, within key qualitative rating factors, Moody's views banks in mature markets and banks in developing markets differently because the regulatory framework in these countries as often more uncertain and the environment is generally more unstable. In the same vein, the review of the specific documentation of the CRA relating to the sovereign rating indicates that the country level of development is an important indicator in the allocation of this rating (S\&P's, 2011a, 2012; Moody's, 1999c, 2008; FitchRatings, August 2012a, b). All these findings suggest the following main hypothesis:

\section{MH: "The rating process of DdC banks differs partly from this of $D g C$ ".}

To test our main hypothesis, we are looking for any structural difference between bank groups in the influence that components or factors or variables have on the 'all-in' ratings using CAMELS model with ' $\mathrm{S}$ ' adjusted to BCRR. To become more pragmatic, from this main hypothesis, we can derive four sub-hypotheses which will allow us to specify the nature of the differences in the rating process.

As exposed above and to highlight, Shen et al. (2012) found that the intrinsic credit quality assessment factors summarized in the financial ratios are more important for the allocation of DdC BCRR than for those of $\operatorname{DgC}$. In addition, Orsenigo and Vercellis (2013) have shown that some variables are relevant to all regions, others are region-specific. And Peresetsky and Karminsky (2011) have shown that support factor is more important for the allocation of $\mathrm{DgC}$ bank ratings than for those of DdC. In particular, the relationship between BCRR and sovereign rating is not of the same importance to banks in both groups. Indeed, Borensztein, Cowan and Valenzuela (2013) showed that the influence of the sovereign ceiling on corporate ratings remains particularly important in countries where capital account restrictions are still in place and in countries with high political risk. Moreover, Williams, Al-sakka and Gwilym (2013) showed that the emerging market BCRR are often constrained by the sovereign ceiling. But they add, to clarify more, although a sovereign ceiling is much more of a problem in emerging economies that tend to have a low sovereign rating, a sovereign ceiling policy can also have important implications for the distressed advanced economies given the recent debt crisis in Europe (Note 2). In the same vein, Al-sakka, Gwilymo and Nhung (2013) found that the banks in DdC 'Portugal, Italy, Ireland, Greece and Spain 'PIIGS"' appear to be more affected by sovereign credit signals than those in other European countries. All these findings suggest the following sub-hypotheses:

SH1 \&2: The first (second) component of the 'all-in' rating has more weight for the allocation of ratings of DdC $(D g C)$ banks than for those of $\mathrm{DgC}(\mathrm{DdC})$.

SH3: Some important factors represented by relevant variables of the 'all-in' ratings are specific to each bank group (DdC and $\mathrm{DgC}$ ) and others are the same for both groups, but with a difference in the influence on the 'all-in' rating assigned.

SH4: Sovereign rating is more relevant for the allocation of the ratings of the DgC bank group than for those of $D d C$.

The confirmation of our main hypothesis doesn't need necessary the confirmation of all sub-hypotheses, but at least one of the four.

\section{Methodological Aspects}

\subsection{The Explanatory Variables}

The explanatory variables selected to measure each factor are extracted from the work of Damak (2018): 10 variables of the CAMEL factors for 'intrinsic credit quality' component and 4 variables for 'environmental support' component. They are presented in table 2. All CAMEL variables are three-year averages that precede the rating year (Note 3). This 
approach, called 'Through-The-Cycle', neutralizes the impact of the business cycle on ratings, in order to obtain indicators less dependent on the characteristics of the business issuers' financial statements (Amato, Ferri, Lacitignola, \& Sinisi, 2013). The source of our data is the 'S\&P Capital IQ' database in 2012 (Note 4).

\subsection{The Variables to Explain}

We will conduct our empirical comparative study using S\&P's 'all-in' ratings collected from its website. To capture all the information on the 'all-in' rating process of each group, we chose to conduct the study on rating grades and classes by making numerical conversions (see Table 2).

\subsection{The Control Variable}

We will introduce the variable "level of development of the country 'DdC-DgC'" as a control variable in the regressions that consider both groups at the same time (see Table 2).

Table 2. Variable definitions

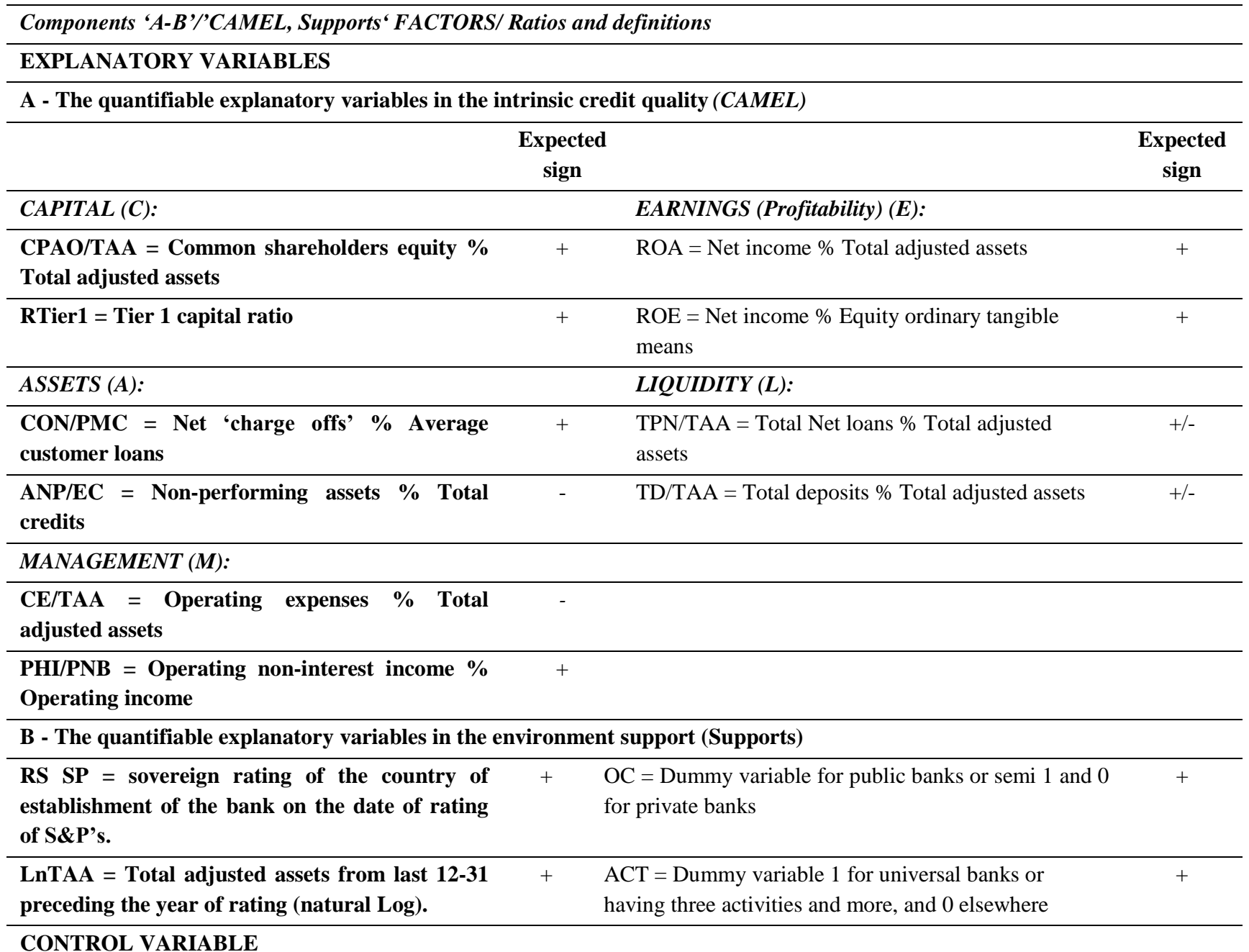

\section{CONTROL VARIABLE}

\section{Expected} sign

DdC-DgC = Level of developing of the country of establishment of the bank: 0 for $\mathrm{DgC}$ and 1 for DdC

VARIABLES TO EXPLAIN 
values assigned to each grade and class of rating

\begin{tabular}{ll}
\hline $\begin{array}{l}\text { VNGSP= Numeric value of 'all-in' rating grade } \\
\text { of } S \& P \text { 's in July 2012. }\end{array}$ & $\begin{array}{l}\text { Investment Grade: } \mathrm{AAA}=17, \mathrm{AA}+=16, \mathrm{AA}=15, \ldots, \mathrm{BBB}+=10, \mathrm{BBB}=9, \\
\end{array}$ \\
$\begin{array}{l}\text { Speculative Grade: } \mathrm{BB}+=7, \quad \mathrm{BB}=6, \quad \mathrm{BB}-=5, \quad \mathrm{~B}+=4, \quad \mathrm{~B}=3, \quad \mathrm{~B}-=2 \quad \text { and } \\
\mathrm{CCC} / \mathrm{CC} / \mathrm{C}=1\end{array}$
\end{tabular}

VNCSP1-5= Numeric value of 'all-in' rating Investment Grade Classes: $\mathrm{AAA} / \mathrm{AA}=5, \mathrm{~A}=4, \mathrm{BBB}=3$; class of S\&P's in July 2012. Speculative Grade Classes: $B B=2$ and $B / C C C / C C / C=1$

Source: This table is taken from Damak (2018) after a small adjustment by the author of the variables to explain to adapt it to the needs of the study.

Table 3. List of countries and number of banks by country group

\begin{tabular}{|c|c|c|c|c|c|}
\hline $\begin{array}{l}\text { Developed } \\
\text { Country list }\end{array}$ & $\begin{array}{c}\text { Sovereign rating } \\
\text { S\&P's }\end{array}$ & $\begin{array}{c}\mathrm{N}^{\circ} \\
\text { banks }\end{array}$ & $\begin{array}{l}\text { Developing } \\
\text { Country list }\end{array}$ & $\begin{array}{c}\text { Sovereign rating } \\
\text { S\&P's }\end{array}$ & $\mathrm{N}^{\circ}$ banks \\
\hline 1 Austria & $\mathrm{AA}+$ & 4 & 1 Belarus & B- & 4 \\
\hline 2 Belgium & AA & 7 & 2 Bulgaria & $\mathrm{BBB}$ & 2 \\
\hline 3 Denmark & AAA & 3 & 3 Croatia & BBB- & 1 \\
\hline 4 Finland & AAA & 1 & 4 R-Czech & AA- & 2 \\
\hline 5 France & AA & 18 & 5 Georgia & BB- & 1 \\
\hline 6 Germany & AAA & 12 & 6 Hungary & $\mathrm{BB}+$ & 5 \\
\hline 7 Greece & $\mathrm{CCC} / \mathrm{CC} / \mathrm{C}$ & 3 & 7 Lithuania & $\mathrm{BBB}$ & 1 \\
\hline 8 Ireland & $\mathrm{BBB}+$ & 9 & 8 Poland & A- & 6 \\
\hline 9 Italy & $\mathrm{BBB}+$ & 26 & 9 Russia & $\mathrm{BBB}$ & 34 \\
\hline $\begin{array}{l}10 \\
\text { Liechtenstein }\end{array}$ & AAA & 2 & 10 Slovakia & A & 1 \\
\hline $\begin{array}{l}11 \\
\text { Luxembourg }\end{array}$ & AAA & 2 & 11 Slovenia & $\mathrm{A}+$ & 1 \\
\hline 12 Netherlands & AAA & 11 & 12 Turkey & $\mathrm{BB}$ & 5 \\
\hline 13 Norway & AAA & 2 & 13 Ukraine & $\mathrm{B}+$ & 2 \\
\hline 14 Portugal & $\mathrm{BB}$ & 4 & 14 Egypt & B & 4 \\
\hline 15 Spain & $\mathrm{BBB}+$ & 13 & 15 Jordan & $\mathrm{BB}$ & 1 \\
\hline 16 Switzerland & AAA & 13 & 16 Libanon & B & 3 \\
\hline 17 Sweden & AAA & 10 & 17 Marocco & BBB- & 3 \\
\hline 18 G-Britain & AAA & 10 & 18 Tunisia & $\mathrm{BB}$ & 5 \\
\hline $\mathbf{N}^{\circ}$ banks & & 150 & $\mathbf{N}^{\circ}$ banks & & 81 \\
\hline
\end{tabular}

Source. This table is the author's construction from the collected data.

Note. For the distribution of countries by level of development, we used the 2012 Development Assistance Committee ranking.

\subsection{Sample Characteristics}

We will conduct our structural breaks across country groups (DdC/DgC) on a sample of banks from Europe, Middle East and North Africa (EMENA). It's composed of 231 rated banks in 2012 (with 150 banks from 18 DdC and 81 banks from $18 \mathrm{DgC}$ ) (see table 3). The choice of European banks is mainly motivated by two reasons. The first is the fact that the region of Europe has the highest number of banks rated (Shen et al., 2012). And the second is that the movement of bank rating adjustments across the universe, based on a revised methodology in the first half of 2012 , has 
led to many changes, mainly downgrades, in the ratings of banks in European countries (Packer \& Tarashev, 2011; Moody's, 2012a). The consideration of banks in the Middle East and North Africa is to fill the small number of banks in the $\mathrm{DgC}$ group in the European region, which is likely to create modelling constraints. We used the rating of July 2012 (the date of the end of the revision of all ratings) to consider all changes made by S\&P's during the revision of the BCRR methodology in response to the global and European crisis.

\subsection{Analytical Methods}

After univariate (Note 5) and bivariate (Note 6) descriptive analyses, we will use "ordered logit 'OLOGIT" "regression (Scott \& Freese, 2006) for the numerical value of the rating classes (decreasing scale of 5 to 1 ). In order to capture as many relevant variables as possible, we will complete our analysis with a multiple linear regression (according to the method of the ordinary least squares 'OLS') of the numerical value of the rating grades (decreasing scale of 17 to 1 ) (Note 7).

To test the validity of our hypotheses, we will do this in three steps. In the first one, we will, run the regressions of the following four equations from (1) to (4) for each group (DdC and $\mathrm{DgC}$ banks).

$$
\begin{gathered}
\text { Rating 'all-in' }{ }_{i k t}=f\left(C_{\text {CAMEL 'S' }}\right)=f\left(A_{i k t-1}+B_{i k t}\right)+\varepsilon_{l i k t} \\
\text { Rating 'all-in' }{ }_{i k t}=f(C A M E L)=f\left(A_{i k t-1}\right)+\varepsilon_{2 i k t} \\
\text { Rating 'all-in' }{ }_{i k t}=f(\text { Supports })=f\left(B_{i k t}\right)+\varepsilon_{3 i k t} \\
\text { Rating 'all-in' }{ }_{i k t}=f(\text { Sovereign Rating })=f\left(R S_{i k t}\right)+\varepsilon_{4 i k t}
\end{gathered}
$$

Where, Rating 'all-in' ${ }_{\mathrm{ikt}}$ is the vector of 'all-in' rating class or grade of the bank $\mathrm{i}$ of group $\mathrm{k}(\mathrm{k}=\mathrm{DdC}$ or $\mathrm{DgC})$ in the period $\mathrm{t}(\mathrm{t}=2012)$.

$\mathrm{A}_{\mathrm{ikt}-1}$ is the matrix of 10 quantifiable variables (see table 2) for the assessment of the intrinsic credit quality of the bank i of group $\mathrm{k}(\mathrm{k}=\mathrm{DdC}$ or $\mathrm{DgC})$. They are three-year averages preceding the period $\mathrm{t}(\mathrm{t}=2012)$.

$B_{i k t}$ is the matrix of 4 quantifiable variables (see table 2) for the evaluation of the environment supports of the bank $i$ of group $\mathrm{k}(\mathrm{k}=\mathrm{DdC}$ or $\mathrm{DgC})$ in the period $\mathrm{t}(\mathrm{t}=2012)$.

$\mathrm{RS}_{\mathrm{ikt}}$ is the vector of the S\&P's sovereign rating of the country of establishment of the bank $\mathrm{i}$ in the period $\mathrm{t}(\mathrm{t}=2012)$.

$\varepsilon_{\text {pikt }}$ are the vectors of the residues of the $\mathrm{p}^{\text {th }}$ equation $(\mathrm{p}=1,2,3,4)$. The error term represents the part of the specification error and captures all the private information that are formed by the confidential information held by CRAs about the bank i of group $\mathrm{k}(\mathrm{k}=\mathrm{DdC}, \mathrm{DgC})$ in the period $\mathrm{t}(\mathrm{t}=2012)$ and the interpretation of the expert group in charge of the folder.

In the second step, we will compare the signification thresholds of the DdC-DgC coefficients and the explanatory powers of the regressions of the 'all-in' rating equations (from 1 to 3) in 2012 to emphasize the component weights in each group.

In the third and last step, we will compare the rating processes intragroup (grade and class regressions) and intergroup (DdC and DgC banks) to underline the important factors, the relevant variables and signification thresholds of some variable coefficients in 'all-in' rating regressions in 2012.

The explanatory powers of the OLS and OLOGIT regressions are measured respectively by 'adjusted R2' and 'Pseudo $R 2$ '. The explanatory powers of the equation (1) regressions provide information on the quality of the specification of CAMELS model with adjusted 'S'. High explanatory power indicates good specification. The weight of component 1 in the attribution of the 'all-in' rating can be measured by the importance of the explanatory power of the equation (2) regression and the difference between the explanatory powers of the regressions of equations (1) and (3). And the weight of component 2 can be measured by the importance of the explanatory power of the equation (3) regressions and the difference between the explanatory powers of the regressions of equations (1) and (2). A factor is qualified as important when at least one of the variables that measures it is relevant. A variable qualifies as relevant when its regression coefficient is significant at the thresholds of $1 \%$ or $5 \%$ or $10 \%$. The relative relevance of the sovereign rating variable can be measured by the importance of the explanatory power of the equation (4) regression and the low difference between the explanatory powers of the regressions of equations (1) and (4).

For each regression, we will proceed to diagnose the multicollinearity with the «Variance Inflation Factor 'VIF'» (Note 8) and diagnose the model stability with «Bootstrap Inclusion Fractions 'BIF'» (Note 9) advocated by Nunez, Steyerberg and Nunez (2011). For checking the accuracy of the "proportional odds assumption" in 'all-in' rating regressions measured by classes, we use the likelihood-ratio test (Note 10) (Dolgun \& Saracbasi, 2014). For diagnosing heteroskedasticity in 'all-in' rating regressions measured by grades, we use the «Breusch-Pagan» test 
(Note 11).

And given that the number of observations in our sample is not important for taking a subsample, we will test the robustness of our hypotheses by using the bootstrapping approach (Royston \& Sauerbrei, 2009) with 1000 replications for regressions of the equations.

\section{Analysis of Results}

\subsection{Univariate and Bivariate Descriptive Analyses}

The sample distribution of 231 banks ( 150 from DdC and 81 banks from $\mathrm{DgC}$ ) rated in 2012 distinguishing the five classes of the 'all-in' rating and the country group are presented in Table 4 . The frequencies (in\%) of the bank ratings of $\mathrm{DdC}$ and $\mathrm{DgC}$ show a distribution of ratings over the two categories (investment and speculative) but with remarkable differences in the frequencies. The $80.25 \%$ of the ratings of the $\mathrm{DgC}$ banks are speculative ratings against only $12.67 \%$ of the DdC banks.

Table 4. Descriptive statistics by class and country group

\begin{tabular}{|c|c|c|c|c|c|c|c|c|c|c|}
\hline \multirow{3}{*}{$\begin{array}{c}\text { Bank country goup } \\
\text { Rating category } \\
\text { S\&P's rating class } \\
\end{array}$} & \multicolumn{5}{|c|}{ Dd } & \multicolumn{5}{|c|}{ Dg } \\
\hline & \multicolumn{3}{|c|}{ Investment } & \multicolumn{2}{|c|}{ Speculative } & \multicolumn{3}{|c|}{ Investment } & \multicolumn{2}{|c|}{ Speculative } \\
\hline & $\begin{array}{l}\mathrm{AAA} / \\
\mathrm{AA}\end{array}$ & A & $\mathrm{BBB}$ & $\mathrm{BB}$ & $\begin{array}{c}\mathrm{B} / \mathrm{CCC} / \\
\mathrm{CC} / \mathrm{C}\end{array}$ & $\begin{array}{l}\mathrm{AAA} / \\
\mathrm{AA}\end{array}$ & A & $\mathrm{BBB}$ & $\mathrm{BB}$ & $\begin{array}{r}\mathrm{B} / \mathrm{CCC} / \\
\mathrm{CC} / \mathrm{C}\end{array}$ \\
\hline $\begin{array}{l}\text { Numerical value } \\
\text { assigned }\end{array}$ & 5 & 4 & 3 & 2 & 1 & 5 & 4 & 3 & 2 & 1 \\
\hline \multicolumn{11}{|c|}{ Sub-simple distributions in 2012 (231 Banks: 150 from DdC and 81 from DgC) } \\
\hline Frequency & 25 & 58 & 48 & 13 & 6 & 0 & 4 & 12 & 27 & 38 \\
\hline Freq. in \% & 16,67 & 38,66 & 32,00 & 8,67 & 4,00 & 0 & 4,94 & 14,81 & 33,33 & 46,92 \\
\hline Cumulative freq. in $\%$ & 16,67 & 55,34 & 87,34 & 96,00 & 100,00 & 0 & 4,94 & 19,75 & 53,08 & 100,00 \\
\hline $\begin{array}{c}\text { Frequency by category } \\
\text { of rating in } \%\end{array}$ & & 87,33 & & & & & 19 & & & 25 \\
\hline
\end{tabular}

Source. This table is the author's construction.

The descriptive analysis of the explanatory variables by rating class and by bank group shows, for some variables, a convergence between the two groups and for other variables a divergence in the relationship. For the two groups of banks ( $\mathrm{DdC}$ and $\mathrm{DgC}$ ), the decrease in RSSP is perfectly consistent with bad risk rating classes. While the decrease in RTier1 (ranging from 13.92 to 8.26) and ROA (ranging from 0.72 to -3.90) influence negatively the ratings of DdC banks. On the other hand, the increase in CON/PMC (ranging from 0.25 to 1.79), CE/TAA (ranging from 3.88 to 8.57 ) and the decrease in ROE (ranging from 15.86 to 5.45) and TAA-LnTAA influence negatively the ratings of banks in $\mathrm{DgC}$.

The comparison of the proportions of banks wholly or partially owned by the State (the variable 'origin of capital' measured by the dummy variable OC) by rating class, of each group shows that the DdC banks wholly or partially owned by the State are better classified by S\&P's unlike $\mathrm{DgC}$ banks. The comparison of the proportions of universal banks (the 'bank activity' variable measured by the dummy variable ACT) by rating class, of each group shows that for the group of DdC banks, universal banks obtain better 'all-in' rating classes but from class A (which excludes AAA/AA). The influence of other variables in the 'all-in' rating is not clear for the two groups of banks.

After the descriptive analyzes of the subsample of the DdC banks and those of the $\mathrm{DgC}$ for the detection of certain trends, we will move on to the bivariate analysis and use the Student test for comparing the averages of the variables between these two groups. As expected, the banks of the DdC exhibit better 'all-in' ratings than those of the banks of the $\mathrm{DgC}$. The comparisons of the averages of the variables to explain show that the 'all-in' rating averages (grades and classes) for the samples of $150 \mathrm{DdC}$ banks and $81 \mathrm{DgC}$ banks are respectively A- and A for DdC banks and BBand $\mathrm{BB}$ for $\mathrm{DgC}$ banks (the corresponding grade and class numerical values by bank group are respectively 10,70 and 3,55 for DdC banks and 5,16 and 1,78 for DgC banks). Theirs student tests are significant at the $1 \%$ threshold.

Despite the differences in the nonsignificant averages of some variables, the banks of DdC and $\mathrm{DgC}$ differ in all 
factors (CAMEL and Supports). Indeed, the banks of the DdC compared to those of the $\mathrm{DgC}$ (t-student is significant) are less capitalized (the average of CPAO/TAA is lower for the DdC banks), more efficient (the average of CE/TAA is lower for DdC banks) and less liquid (the average of TD/TAA is lower for DdC banks). Also, they are established in countries with a high sovereign rating (the RSSP average is higher for DdC banks) and large (TAA and LnTAA averages are higher for DdC banks). And they have better asset quality (the average of ANP/EC is lower for DdC banks).

\subsection{Multivariate Analysis}

The results of the regressions of the equation (1) (Note 13) by OLS and OLOGIT with the samples of 150 banks of DdC and 81 banks of $\mathrm{DgC}$ in 2012 using the 'all-in' ratings of S\&P's for both measures (grades and classes) are presented in table 5. The explanatory powers of the four equations are summarized in table 6 .

The regressions of the four equations with the control variable "Level of developing of the country of establishment of the bank ' $D d C-D g C$ '" as a dummy variable ( 0 for $\mathrm{DgC}$ and 1 for $\mathrm{DdC})$ and samples from both groups $(150+81=231$ banks) with the grade then with the class (reported for the equation (1) in table 5, columns $1 \& 2$ respectively) show three results. Firstly, the coefficients with the positive signs of this variable are significant at the thresholds of $1 \%$ for the four class regressions and for the two grade regressions of the equations (2) and (4). And they are significant at the thresholds of $5 \%$ for the grade regressions of the equations (1) and (3). This result confirms once again the downward trend in the ratings between $\mathrm{DdC}$ and $\mathrm{DgC}$.

Table 5. The results of equation (1) estimates

\begin{tabular}{|c|c|c|c|c|c|c|}
\hline \multirow{2}{*}{$\begin{array}{c}\text { Bank country group } \\
\text { Results }\end{array}$} & \multicolumn{2}{|c|}{ Dd-Dg } & \multicolumn{2}{|c|}{ Dd } & \multicolumn{2}{|c|}{$\mathrm{Dg}$} \\
\hline & OLS & OLOGIT & OLS & OLOGIT & OLS & OLOGIT \\
\hline Variable to explain & VNGSP & VNCSP15 & VNGSP & VNCSP15 & VNGSP & VNCSP15 \\
\hline \multirow[t]{2}{*}{ Column } & 1 & 2 & 3 & 4 & 5 & 6 \\
\hline & $\begin{array}{c}\text { Coef. } \\
\text { (P-values) }\end{array}$ & $\begin{array}{c}\text { Coef. } \\
\text { (P-values) }\end{array}$ & $\begin{array}{c}\text { Coef. } \\
\text { (P-values) }\end{array}$ & $\begin{array}{c}\text { Coef. } \\
\text { (P-values) }\end{array}$ & $\begin{array}{c}\text { Coef. } \\
\text { (P-values) }\end{array}$ & $\begin{array}{c}\text { Coef. } \\
\text { (P-values) }\end{array}$ \\
\hline Constant & $\begin{array}{c}\mathbf{- 5 . 4 5 1 5} * * * \\
(0.000)\end{array}$ & & $\begin{array}{l}-1.6291 \\
(0.372)\end{array}$ & & $\begin{array}{c}\mathbf{- 1 1 . 9 0 1 7} * * * \\
(0.000)\end{array}$ & \\
\hline \multicolumn{7}{|c|}{ A-Intrinsic credit quality (CAMEL) } \\
\hline \multicolumn{7}{|l|}{ Capital } \\
\hline CPAO/TAA & $\begin{array}{l}\mathbf{0 . 1 3 1 1} * * * \\
(0.000)\end{array}$ & $\begin{array}{l}\mathbf{0 . 1 4 3 8 * * * *} \\
(0.000)\end{array}$ & $\begin{array}{l}\mathbf{0 . 0 7 1 1} * \\
(0.090)\end{array}$ & $\begin{array}{l}0.0939 \\
(0.124)\end{array}$ & $\begin{array}{c}\mathbf{0 . 1 6 7 0} * * * * \\
(0.000)\end{array}$ & $\begin{array}{c}\mathbf{0 . 2 1 5 0} * * * \\
(0.004)\end{array}$ \\
\hline RTier1 & $\begin{array}{l}-0.0004 \\
(0.985)\end{array}$ & $\begin{array}{l}0.0004 \\
(0.988)\end{array}$ & $\begin{array}{l}0.0155 \\
(0.655)\end{array}$ & $\begin{array}{l}0.0043 \\
(0.903)\end{array}$ & $\begin{array}{l}-0.0350 \\
(0.217)\end{array}$ & $\begin{array}{l}-0.0331 \\
(0.454)\end{array}$ \\
\hline \multicolumn{7}{|l|}{ Assets } \\
\hline CON/PMC & $\begin{array}{l}0.0289 \\
(0.686)\end{array}$ & $\begin{array}{l}-0.2750 \\
(0.237)\end{array}$ & $\begin{array}{l}-0.4465 \\
(0.251)\end{array}$ & $\begin{array}{c}\mathbf{- 0 . 7 1 4 6 *} \\
(0.100)\end{array}$ & $\begin{array}{l}0.0415 \\
(0.512)\end{array}$ & $\begin{array}{l}-0.0482 \\
(0.882)\end{array}$ \\
\hline$A N P / E C$ & $\begin{array}{c}\mathbf{- 0 . 0 5 3 1 * *} \\
(0.050)\end{array}$ & $\begin{array}{l}-0.0397 \\
(0.201)\end{array}$ & $\begin{array}{l}-0.0155 \\
(0.724)\end{array}$ & $\begin{array}{l}0.0088 \\
(0.848)\end{array}$ & $\begin{array}{l}-0.0185 \\
(0.610)\end{array}$ & $\begin{array}{l}-0.0519 \\
(0.437)\end{array}$ \\
\hline \multicolumn{7}{|l|}{ Management } \\
\hline$C E / T A A$ & $\begin{array}{c}\mathbf{- 0 . 1 5 6 1 * *} \\
(0.012) \\
\end{array}$ & $\begin{array}{c}-\mathbf{0 . 1 8 6 6} * * * \\
(0.010)\end{array}$ & $\begin{array}{l}-0.0816 \\
(0.381)\end{array}$ & $\begin{array}{l}-0.0591 \\
(0.521)\end{array}$ & $\begin{array}{c}\mathbf{- 0 . 2 0 1 8} * * * \\
(0.009)\end{array}$ & $\begin{array}{c}\mathbf{- 0 . 4 7 7 6} * * * \\
(0.003)\end{array}$ \\
\hline$P H I / P N B$ & $\begin{array}{l}0.0008 \\
(0.531)\end{array}$ & $\begin{array}{l}-0.0002 \\
(0.860)\end{array}$ & $\begin{array}{l}0.0008 \\
(0.576)\end{array}$ & $\begin{array}{c}-0.00001 \\
(0.996)\end{array}$ & $\begin{array}{l}0.0083 \\
(0.130)\end{array}$ & $\begin{array}{c}\mathbf{0 . 0 2 0 1} * * * \\
(0.038)\end{array}$ \\
\hline \multicolumn{7}{|l|}{ Earnings } \\
\hline$R O A$ & $\begin{array}{l}0.0686 \\
(0.369)\end{array}$ & $\begin{array}{c}0.0715 \\
(0.425)\end{array}$ & $\begin{array}{c}\mathbf{0 . 4 6 7 9} * * * \\
(0.005)\end{array}$ & $\begin{array}{c}\mathbf{0 . 7 0 9 3} * * \\
(0.013)\end{array}$ & $\begin{array}{l}-0.0726 \\
(0.314)\end{array}$ & $\begin{array}{l}-0.1174 \\
(0.274)\end{array}$ \\
\hline$R O E$ & $\begin{array}{l}-0.0001 \\
(0.627)\end{array}$ & $\begin{array}{c}-0.00001 \\
(0.994)\end{array}$ & $\begin{array}{l}0.0001 \\
(0.831)\end{array}$ & $\begin{array}{l}0.0002 \\
(0.842)\end{array}$ & $\begin{array}{l}-0.0050 \\
(0.752)\end{array}$ & $\begin{array}{l}-0.0024 \\
(0.936)\end{array}$ \\
\hline
\end{tabular}

Liquidity 


\begin{tabular}{|c|c|c|c|c|c|c|}
\hline TPN/TAA & $\begin{array}{r}0.00267 \\
(0.679)\end{array}$ & $\begin{array}{l}-0.0026 \\
(0.696)\end{array}$ & $\begin{array}{l}-0.0052 \\
(0.495)\end{array}$ & $\begin{array}{c}\mathbf{- 0 . 0 1 4 0 *} \\
(0.079)\end{array}$ & $\begin{array}{c}\mathbf{0 . 0 3 4 2} * * \\
(0.021)\end{array}$ & $\begin{array}{c}\mathbf{0 . 0 5 9 7} * * \\
(0.021)\end{array}$ \\
\hline \multirow[t]{2}{*}{$T D / T A A$} & $0.0140 *$ & 0.0128 & 0.0115 & 0.0088 & 0.0293 & 0.0350 \\
\hline & $(0.055)$ & $(0.103)$ & $(0.158)$ & $(0.315)$ & $(0.146)$ & $(0.315)$ \\
\hline \multicolumn{7}{|c|}{ B-Environment Supports ('S') } \\
\hline \multirow[t]{2}{*}{$R S S P$} & $0.5709 * * *$ & $0.5505 * * *$ & $0.5646 * * *$ & $0.5767 * * *$ & $\mathbf{0 . 4 5 5 5} * * *$ & $0.6062 * * *$ \\
\hline & $(0.000)$ & $(0.000)$ & $(0.000)$ & $(0.000)$ & $(0.000)$ & $(0.000)$ \\
\hline \multirow[t]{2}{*}{$\operatorname{LnTAA}$} & $0.5560 * * *$ & $0.4889 * * *$ & $0.3447 * * *$ & $0.2700 * *$ & $1.0264 * * *$ & $1.3001 * * *$ \\
\hline & $(0.000)$ & $(0.000)$ & $(0.004)$ & $(0.034)$ & $(0.000)$ & $(0.000)$ \\
\hline \multirow[t]{2}{*}{$O C$} & $0.7588 * *$ & $0.6496 *$ & $0.9059 * *$ & $1.0310 * *$ & 0.4201 & 0.3387 \\
\hline & $(0.016)$ & $(0.056)$ & $(0.031)$ & $(0.024)$ & $(0.311)$ & $(0.602)$ \\
\hline \multirow[t]{2}{*}{$A C T$} & -0.2120 & -0.0655 & -0.0807 & 0.2962 & 0.3442 & 0.2941 \\
\hline & $(0.453)$ & $(0.822)$ & $(0.826)$ & $(0.426)$ & $(0.361)$ & $(0.623)$ \\
\hline \multicolumn{7}{|l|}{ Control variable } \\
\hline \multirow[t]{2}{*}{ DdC-DgC } & $1.1241 * *$ & $1.3299 * * *$ & & & & \\
\hline & $(0.013)$ & $(0.004)$ & & & & \\
\hline $\mathbf{N}^{\circ}$ d'observation & 231 & 231 & 150 & 150 & 81 & 81 \\
\hline \multicolumn{7}{|c|}{ Diagnostics of the explanatory power } \\
\hline $\mathbf{R 2}$ & 0.7767 & & 0.6621 & & 0.7397 & \\
\hline R2 Adj & 0.7611 & & 0.6270 & & 0.6845 & \\
\hline Prob> chi2 & & 0,0000 & & 0,0000 & & 0,0000 \\
\hline Pseudo R2 & & 0.4295 & & 0.3602 & & 0.4751 \\
\hline \multicolumn{7}{|c|}{ Diagnostics of multicolinearity $^{I}$} \\
\hline VIF Moyen & 1.60 & 1.60 & 1.56 & 1.56 & 1.66 & 1.66 \\
\hline VIF Max & 2.67 & 2.67 & 2.50 & 2.50 & 2.20 & 2.20 \\
\hline \multicolumn{7}{|c|}{ Diagnostics of model stability $^{2}$} \\
\hline$\%$ BIF min (Vi) 1000 & $45.50 \%$ & $57.60 \%$ & $48.00 \%$ & $41.50 \%$ & $51.60 \%$ & $49.20 \%$ \\
\hline rep. & $(\mathrm{TD} / \mathrm{TAA})$ & $(\mathrm{OC})$ & (CPAO/TAA) & $(\mathrm{CON} / \mathrm{PMC})$ & (TPN/TAA) & $(\mathrm{PHI} / \mathrm{PNB})$ \\
\hline$\%$ BIF max (Vi) & $100 \%$ & $100 \%$ & $100 \%$ & $100 \%$ & $100 \%$ & $99.90 \%$ \\
\hline 1000 rep. & (RSSP, LnTAA) & (RSSP, LnTAA) & $(\mathrm{RSSP})$ & $(\mathrm{RSSP})$ & (LnTAA) & (LnTAA) \\
\hline \multicolumn{7}{|c|}{ Diagnosis of proportional odds ${ }^{3}$} \\
\hline \multicolumn{7}{|l|}{ Likelihood-ratio test } \\
\hline chi2 & & 71.79 & & 61.06 & & 41.82 \\
\hline Prob $>$ chi 2 & & 0.0068 & & 0.0288 & & 0.0450 \\
\hline \multicolumn{7}{|c|}{ Diagnostics of heteroskedasticity ${ }^{4}$} \\
\hline \multicolumn{7}{|l|}{ Breusch-Pagan } \\
\hline chi2 & 2.77 & & 6.45 & & 2.37 & \\
\hline Prob $>$ chi2 & 0.0959 & & 0.0111 & & 0.1236 & \\
\hline
\end{tabular}

Source. Author' calculation.

Notes. 1-By calculating the Variance Inflation Factor (VIF). 2-By using the "Bootstrap Inclusion Fractions 'BIF"” test with 1000 replications.

The model is even more stable that the BIF minimum is high. The \% BIF min. (Vi) 1000 rep. is the percentage of minimum 'BIF' of the significant variable (vi) with 1000 replications. The $\%$ BIF max (Vi) 1000 rep. is the percentage of maximum 'BIF' of the significant variable (vi) with 1000 replications. 3-High Chi2 and low "p-value" indicate the presence of proportional odds approach. 4-High Chi2 and low "p-value" indicate the presence of heteroskedasticity.

Variable definitions. See Table 2. 
Table 6. The regression explanatory power summary of the equations from (1) to (4)

\begin{tabular}{ccccccc}
\hline Regression & OLS & OLOGIT & \multicolumn{2}{c}{ OLS } & \multicolumn{2}{c}{ OLOGIT } \\
\hline Variable to explain & VNGSP & VNCSP15 & \multicolumn{2}{c}{ VNGSP } & \multicolumn{2}{c}{ VNCSP15 } \\
Explanatory power & $\mathbf{R 2}$ ajusté & Pseudo $\mathbf{R} 2$ & \multicolumn{2}{c}{ R2 ajusté } & \multicolumn{2}{c}{ Pseudo $\boldsymbol{R 2}$} \\
Bank group country & Dd-Dg & Dd-Dg & Dd & Dg & Dd & Dg \\
Column & $\mathbf{1}$ & $\mathbf{2}$ & $\mathbf{3}$ & $\mathbf{4}$ & $\mathbf{5}$ & $\mathbf{6}$ \\
$\mathbf{N}^{\circ}$ observation & $\mathbf{2 3 1}$ & $\mathbf{2 3 1}$ & $\mathbf{1 5 0}$ & $\mathbf{8 1}$ & $\mathbf{1 5 0}$ & $\mathbf{8 1}$ \\
Equation (1) & 0.7611 & 0.4295 & 0.6270 & $\mathbf{0 . 6 8 4 5}$ & 0.3602 & $\mathbf{0 . 4 7 5 1}$ \\
Equation (2) & 0.5143 & 0.2341 & $\mathbf{0 . 2 9 8 4}$ & 0.2971 & 0.1180 & $\mathbf{0 . 2 1 1 1}$ \\
Equation (3) & 0.7184 & 0.3721 & 0.5396 & $\mathbf{0 . 5 9 7 3}$ & 0.2671 & $\mathbf{0 . 3 3 3 1}$ \\
Equation (4) & 0.6934 & 0.3431 & $\mathbf{0 . 5 5 1 1}$ & 0.2650 & $\mathbf{0 . 2 5 9 8}$ & 0.1136 \\
$\mathbf{N}^{\circ}$ observation (a) & $\mathbf{2 3 1 - 5 5 = 1 7 6}$ & $\mathbf{2 3 1 - 5 5 = 1 7 6}$ & $\mathbf{1 5 0 - 5 5 = 9 5}$ & & $\mathbf{1 5 0 - 5 5 = 9 5}$ & \\
Equation (4) (b)(c) & & & 0.0056 & $\mathbf{0 . 2 6 5 0}$ & 0.0047 & $\mathbf{0 . 1 1 3 6}$ \\
Explanatory power comparaisons & & & & & & \\
Eq.(1) - Eq.(2) & 0.2468 & 0.1954 & 0.3286 & $\mathbf{0 . 3 8 7 4}$ & 0.2422 & $\mathbf{0 . 2 6 4 0}$ \\
Eq.(1) - Eq.(3) & 0.0427 & 0.0574 & $\mathbf{0 . 0 8 7 4}$ & 0.0872 & 0.0931 & $\mathbf{0 . 1 4 2 0}$ \\
\hline
\end{tabular}

Source. Author' calculation.

Equation (1): Rating'all-in' $=f(C A M E L$, Supports)

Equation (2): Rating 'all-in' $=f(C A M E L)$

Equation (3): Rating 'all-in' $=f($ Supports $)=f(R S$, LnTAA, OC, ACT)

Equation (4): Rating 'all-in' $=f($ sovereign rating ' $R S$ ')

a- The number of observations of DdC banks with a numerical value of sovereign rating grades greater than or equal to 15 (AA rating) (elimination of Portugal (4 banks), Italy (26 banks), Ireland ( 9 banks), Greece (3 banks) and Spain (13 banks)).

b- The equation (4) was regressed with the DdC banks with a numerical value of sovereign rating grades greater than or equal to 15 (AA rating). The number of banks (observations) is 95 .

c- The correlations (using the Pearson coefficient) between the variables RS SP and DdC-DgC are $64.37 \%$ with the entire sample of 231 banks and $91.80 \%$ with the subsample of $176(95+81)$ banks after the elimination of the 55 GIIPS banks. We don't regress the equation (4) with the dummy variable DdC-DgC with the subsample 176 banks because of the multicollinearity problem caused by a high correlation.

Secondly, the high meaning thresholds (1\%) of the $D d C-D g C$ coefficients in the regressions of the equation (2) can provide information on the difference in the weight of the first component 'Intrinsic credit quality' represented by CAMEL factors between $D d C$ and $D g C$ banks. This difference is also manifested (see Table 6), on one hand, by the differences in the explanatory powers of the regressions of the equation (2) measured by adjusted R2 (0.2984 for DdC banks and 0.2971 for DgC banks) (columns 3\&4) or Pseudo R2 (0.1180 for DdC banks and 0.2111 for $\operatorname{DgC}$ banks) (columns $5 \& 6$ ). On the other hand, it appears in the differences of regression explanatory powers of equations (1) versus (3) (columns $3 \& 4$ ) for grade regressions ( 0.0874 for DdC banks and 0.0872 for DgC banks) and (columns $5 \& 6$ ) for class regressions ( 0.0931 for DdC banks and 0.1420 for $\mathrm{DgC}$ banks). These results show that the weight of this first component is higher for the allocation of the grade ratings of DdC banks than of DgC banks. So our first sub-hypothesis SHI which states that "The first component of the 'all-in' rating has more weight for the allocation of ratings of DdC banks than for those of $D g C$ " is confirmed for the grades but not for the rating classes.

Thirdly, the significancy of the $D d C-D g C$ variable coefficients in the regressions of the equation (3) inform on the difference in the weight of the second component 'Environment supports' represented by the 'S' factor between $D d C$ and $D g C$ banks. This difference appears (see table 6) in the explanatory powers of the regressions of the equation (3) measured by adjusted R2 (0.5396 for DdC banks and 0.5973 for DgC banks) (columns 3\&4) or Pseudo R2 (0.2671 
for DdC banks and 0.3331 for $\mathrm{DgC}$ banks) (columns 5\&6). It appears also in the differences of regression explanatory powers of equations (1) versus (2) for grade regressions (0.3286 for DdC banks and 0.3874 for $\operatorname{DgC}$ banks) (columns $3 \& 4)$ and for class regressions ( 0.2422 for DdC banks and 0.2640 for DgC banks) (columns $5 \& 6)$. These results inform us about the superior weight of the second component for the allocation of the DgC bank ratings against the DdC bank ratings. So our second sub-hypothesis $\mathrm{SH} 2$ which states that "The second component of the 'all-in' rating has more weight for the allocation of ratings of $D g C$ banks than for those of DdC" is confirmed for the grades and the classes.

The equation (1) regressions (table 5) made with S\&P's 'all-in' ratings of DdC banks (columns $3 \& 4$ ) and DgC banks (columns 5\&6) suggest that the factors of the relevant variables are not, quite, the same in both groups. With regression explanatory powers measured by adjusted R2 or Pseudo R2 exceeding $62.70 \%$ and $36.02 \%$, respectively, and in general, coefficients estimated with the expected signs, the factors: Capital, Liquidity and Supports are important in all the regressions of the two groups. Asset quality and Earnings are important only in the DdC bank regressions. The factor Management is important only for the $\mathrm{DgC}$ bank regressions. So, the spectrum of important factors in the DdC bank regressions is wider than those of $\mathrm{DgC}$ bank. These results indicate a difference in the rating process between $\mathrm{DdC}$ and $\mathrm{DgC}$ banks above all in the factors of intrinsic credit quality.

Specifically, for DdC bank group, S\&P's classed the banks based on Asset quality (measured by CON/PMC), Earnings (measured by ROA) and Liquidity (measured by TPN/TAA) in addition to the factor Supports (measured by RSSP, LnTAA and OC). And to specify the grade in the class, it is also based on other CAMEL fator that is Capital (measured by CPAO/TAA). And for DgC bank group, S\&P's classes the banks and specify the grade in the class based on Capital (measured by CPAO/TAA), Management quality (measured by CE/TAA), Liquidity (measured by TPN/TAA) and factor Supports (measured by RSSP and LnTAA). And to class, it is also based on a second Management variable PHI/PNB. So, the difference is in both some important factors and the variables that measure them. In fact, to rate the DdC banks, S\&P's is based on five factors measured by eight variables while for the $\mathrm{DgC}$ banks on four factors measured by six variables. For the same common relevant variables used by S\&P's for the two bank groups, we see a difference in the significance thresholds of their coefficients. We indicated, as examples from table 5, Capital variable CPAO/TAA and Liquidity variable TPN/TAA. They have a significance thresholds inferior for DdC bank group (10\%) (columns 3\&4) than for $\mathrm{DgC}$ bank group (respectively $1 \%$ and 5\%) (columns 5\&6).

Moreover, additional detail on the difference in the relevance of the variable 'bank size' (measured by LnTAA) have caught our attention. It appears less relevant for DdC bank group in equation (1) class regression (table 5) (significant coefficient but at a threshold of 5\% for DdC bank group (column 4) and of $1 \%$ for DgC bank group (column 6)). And it is irrelevant to the DdC bank group in equation (3) regressions (not reported) (not significant coefficient for DdC bank group and highly significant coefficient for $\mathrm{DgC}$ bank group). This result shows the high importance of the famous "too-big-to-fail" principle for the $\mathrm{DgC}$ bank group and his low importance for $\mathrm{DdC}$ bank group. This difference in the consideration of the bank size in the rating of the two groups of banks can be explained by the limits of environmental supports following the bankruptcy of many DdC banks in the subprime crisis (Lehman Brothers among others). These results are sufficient to confirm our third sub-hypothesis $\mathrm{SH} 3$ which states that "Some important factors represented by relevant variables of the 'all-in' ratings are specific to each bank group (DdC and $D g C$ ) and others are the same for both groups, but with a difference in the influence on the 'all-in' rating assigned".

So, it appears that the differences affect the entire rating process, including the weight of the components as well the important factors and the relevant variables. With the confirmation of more than one sub-hypothesis, our main hypothesis $M H$ which states that "The rating process of DdC banks differs partly from this of DgC" can be easily confirmed.

We formulated also a hypothesis relating to the superior relevance, to the $\operatorname{DgC}$ bank group, of the support variable 'sovereign rating' of the country in which the bank is located. The regression results of the equations (1), (3) and (4) show a high relevance of this variable for the two bank groups. Moreover, the explanatory powers of the regressions of the equation (4) (table 6) measured by adjusted R2 (0.5511 for DdC banks and 0.2650 for $\mathrm{DgC}$ banks) (columns $3 \& 5$ ) and Pseudo R2 (0.2598 for DdC banks and 0.1136 for DgC banks) (columns 5\&6) are higher but for the DdC bank group. Consequently, our fouth sub-hypothesis $\mathrm{SH} 4$ is not confirmed.

This unexpected result can be explained, as pointed out by Williams et al. (2013) and Al-sakka et al. (2013), by the effects of the change in the structure of DdC following the succession of the two global and European crises. The latter engendered a downgrade towards the speculative category of the sovereign ratings of certain European DdC which caused those of the banks to drag on. 
Given the regression results could be influenced by a particular set of banks, we proceeded to do regressions with a variety of subsamples of the group of DdC banks. We eliminated the banks, first, by rating class, then, by cascading sovereign rating, starting with the lowest level to see the evolution of the explanatory powers following each elimination. So we regressed equation (4) with several subsamples of DdC banks. We started by eliminating the banks of the lowest rating classes: B/CCC/CC /C then in addition BB. The results (unreported) have not changed. Then we gradually eliminated the banks by country, starting with the one with the lowest sovereign rating: Greece (sovereign rating $\mathrm{CCC} / \mathrm{CC} / \mathrm{C}(\mathrm{VNG}=1)$ ) then Portugal (sovereign rating $\mathrm{BB}(\mathrm{VNG}=6)$ ) and finally Spain, Ireland and Italy (sovereign rating $\mathrm{BBB}+(\mathrm{VNG}=10))$. The results changed only for the subsample, of the $95(150-55) \mathrm{DdC}$ banks with a sovereign rating greater than or equal to $\mathrm{AA}(\mathrm{VNG}=15)$. This subsample eliminates the DdC banks of Europe, which suffered a severe economic recession following the global and European debt crisis referred to the PIIGS countries 'Portugal, Italy, Ireland, Greece and Spain'. Then, the explanatory powers of the equation (4), regressed with the DdC banks having a sovereign rating greater than or equal to AA (VNG=15) (Table 6), decreased and became lower than the explanatory powers of the equation (4) regressed with the $\mathrm{DgC}$ bank group. Indeed, the adjusted R2 has become $0.56 \%$ less than $26.50 \%$ and the Pseudo $R 2$ has become $0.47 \%$ less than $11.36 \%$. So, our hypothesis $\mathrm{SH} 4$ which stipulates that "Sovereign rating is more relevant for the allocation of the ratings of $\mathrm{DgC}$ bank group than for those of DdC" is become confirmed after the elimination from DdC bank group the banks of PIIGS countries 'Portugal, Italy, Ireland, Greece and Spain'.

So we can say that S\&P's gives considerable importance to the sovereign rating of banks established in DdC PIIGS, similar to that given to banks established in $\mathrm{DgC}$. And the sovereign rating is a criterion of distinction between the groups of banks more relevant than that of the level of development despite the strong correlation of the two variables. This result is also consistent with the statements of S\&P's relating to the importance of the relationship between the BCRR, the level of development and the sovereign rating of the country in which the bank is located widely exposed by Damak and Chichti (2017).

\subsection{Robustness Check}

The results will be commented versus Table 5 (Note 14). For the DdC group, only the two support variable coefficients (RSSP, LnTAA) remained significant for the two regressions (columns 3\&4) with bootstrap approch. All variable coefficients of grade regression (column 5) remained significant and the overall meaning of the class regression (column 6) is lost with this approch for the $\mathrm{DgC}$ group. Also, all $\mathrm{DdC}-\mathrm{DgC}$ variable coefficients in the entire sample regressions of the four equations remained significant. Those results further confirm the main and the first three subhypotheses and better validity for the grade regression of the $\mathrm{DgC}$ group.

\section{Conclusion}

We have been empirically studying whether the BCRR process of S\&P's is different between the DdC and $\operatorname{DgC}$ bank groups. We found evidence that the first component of the 'all-in' rating model (assessment of the intrinsic credit quality) has more weight for the grades of the DdC banks and his second component (environmental support) has more weight for the ratings (grade and class) of the $\mathrm{DgC}$ banks. Some important factors and relevant variables of the 'all-in' ratings are specific to each bank group and others are the same for both groups, but with a difference in the influence on the 'all-in' rating assigned". The factors: Capital, Liquidity and Supports are important for the two groups. Asset quality and Earnings are important only for DdC banks. The factor Management is important only for the DgC banks. In addition, the distinction based on the level of development has partly lost its meaning in favor of the sovereign rating, which has become more significant because of the Europe DdC designated by the PIIGS countries 'Portugal, Italy, Ireland, Greece and Spain' who suffered a severe economic recession following the European debt crisis. The country level of development where the bank is located continued to be relevant but through the sovereign rating of its country which is the most relevant variable to explain the 'all-in' rating. These results also show a consistency between the revealed and practiced methodologies of the S\&P's BCRR.

At the end of this work, we can say that although we have tried to contribute to the existing literature, this research work cannot hide the existence of certain limits. Indeed, we used the CAMELS with an adjusted ' $\mathrm{S}$ ' to consider the peculiarities of the BCRR with a sample of banks of EMENA in the 2012 period. This work can be complemented using samples from other regions. And as a subject of later research, a conceptual reflection for another model consistent with the bank regulatory framework will be useful to improve the assessment of bank risks.

\section{References}

Alogoskoufis, G. (2012, January). Greece's Sovereign Debt Crisis: Retrospect and Prospect. GreeSE Paper (54) Hellenic Observatory Papers on Greece and Southeast Europe, The London School of Economics and Political 
Science.

Al-sakka, R., Gwilymo, A. P., \& Nhung, V. U. T. (2013). Bank and sovereign credit ratings during the European debt crisis. Bangor Business School, Bangor University, UK, working paper.

Amato, P., Ferri, G., Lacitignola, P., \& Sinisi, N. (2013). Searching for consistent indices of rating mobility through the crisis. International Risk Management Conference, Copenhagen Business School, Copenhagen, Denmark, June 24-25. Available at ResearchGate.

Bellotti, T., Matousek, R., \& Stewart, C. (2011a). Are rating agencies' assignments opaque? Evidence from international banks. Expert Systems with Applications, 38(4), 4206-4214.

Bellotti, T., Matousek, R., \& Stewart, C. (2011b). A note comparing support vector machines and ordered choice models predictions of international banks ratings. Decision Support System, 51(3), 682-687.

Bissoondoyal-Bheenick, E., \& Treepongkaruna, S. (2011). An analysis of the determinants of bank ratings: comparison across ratings agencies. Australian Journal of Management, 36(3). https://doi.org/10.1177/0312896211426676

Borensztein, E., Cowan, K., \& Valenzuela, P. (2013). Sovereign ceilings "lite'? The impact of sovereign ratings on corporate ratings. Journal of Banking \& Finance, 37, 4014-4024.

Caporale, G., Matousek, R., \& Stewart, C. (2011). EU banks rating assignments: is there heterogeneity between new and old member countries?. Review of International Economics, 19, 189-206.

Damak, E. (2018). Camels model with a proposed 's' for the bank credit risk rating. International Journal of Economics and Finance, 10(9). https://doi.org/10.5539/ijef.v10n9p69

Damak, E., \& Chichti, J. (2017). L'évolution des méthodologies révélées de la notation du risque du crédit bancaire. Banque \& Stratégie, $\quad 356 . \quad$ Retrieved http://www.revue-banque.fr/banque-investissement-marches-gestion-actifs/article/evolution-desmethodologies-r evelees-

Dolgun, A., \& Osman Saracbasi, O. (2014). Assessing proportionality assumption in the adjacent category logistic regression model. Statistics and Its Interface, 7, 275-295.

Ferri, G., \& Liu, L.G., (2004). How do global credit-rating agencies rate firms from developing countries?. Asian Economic Papers 2:3. The Earth Institute at Columbia University and the Massachusetts Institute of Technology.

Ferri, G., Liu, L-G., \& Majnoni, G. (2001). The role of rating agency assessments in less developed countries: Impact of the proposed Basel guidelines. Journal of Banking \& Finance, 25, 115-148.

FitchRatings. (2011a). Perspectives on bank credit ratings in a changing environment: Overall Rating Approach Maintained But Individual Rating Scale Evolves, Special Report, 07 March.

FitchRatings. (2011b). Global financial institutions rating criteria. Master Criteria, August 16.

FitchRatings. (2011c). Rating Financial Institutions Above the Local Currency Sovereign Rating. Sector-Specific Criteria, 20 Dec.

FitchRatings. (2012a). Sovereign Rating Criteria. Master Criteria, August 13.

FitchRatings. (2012b). Country Ceilings. Cross-Sector Criteria Report, August 13.

Gaillard, N. (2008, January). Les méthodologies de notation souveraine. Thèse de Doctorat, Institut d'Etudes Politiques de Paris.

International Monetary Fund. (2010). The uses and abuses of sovereign credit ratings. Global financial Stability Report.

Laruccia, E., \& Revoltella, D. (2000). Banking system stability in developing and transition economies: an analysis of the determinants of Moody's bank financial strength rating. Banca Commercial eItaliana, WP R2000-1.

Moody's Investors Service. (1999c, March). La notation des souverains par Moody’s. Méthodologie de Notation, Global Credit Research.

Moody's Investors Service. (1999a, April). Risque de crédit bancaire - Cadre d'analyse des établissements bancaires dans les pays développés. Méthodologie de Notation. 
Moody's Investors Service. (1999b, July). Bank Credit Risk in Emerging Markets -- An Analytical Framework. Rating Methodology.

Moody's Investors Service. (2007a, February). Notation BFSR de solidité financière des banques: Méthodologie globale. Méthodologie de Notation.

Moody's Investors Service. (2007b, March). Incorporation of Joint-Default Analysis into Moody's Bank Ratings: A Refined Methodology. Rating Methodology.

Moody's Investors Service. (2008, September). Notation des obligations souveraines. Méthodologie de notation.

Moody's Investors Service. (2012a). Moody's: Global bank ratings likely to decline in 2012. Announcement, Global Credit Research, Jan. 19.

Moody's Investors Service. (2012b). How Sovereign Credit Quality May Affect Other Ratings. Rating Implementation Guidance, February 13.

Moody's Investors Service. (2012c). Incorporation of joint-default analysis into Moody's bank ratings: global methodology. Rating Methodology, March 30.

Moody's Investors Service. (2012d). Banks and Sovereigns: Risk Correlations Constrain Standalone Bank Credit Assessments. Special Comment, April 30.

Nunez, E., Steyerberg, W. E., \& Nunez, J. (2011). Regression modeling strategies. Sociedad Espanola de Cardiologia. Published by Elsevier Espana. https://doi.org/10.1016/j.rec.2011.01.017

Orsenigo, C., \& Vercellis, C. (2013). Linear versus nonlinear dimensionality reduction for banks credit rating prediction. Journal Knowledge Based Systems, 47, 14-22. https://doi.org/10.1016/j.knosys.2013.03.001

Packer, F. \& Tarashev, N. (2011, June). Rating methodologies for banks, BIS Quarterly Review.

Pasiouras, F., Gaganis, C., \& Doumpos, M. (2007). A multi-criteria discrimination approach for the credit rating of Asian banks. Annals of Finance, 3(3), 351-367.

Pasiouras, F., Gaganis, C., \& Zopounidis, C. (2006). The impact of bank regulations, supervision, market structure, and bank characteristics on individual bank ratings: a cross-country analysis. Review of Quantitative Finance and Accounting, 27(4), 403-438.

Peresetsky, A. A., \& Karminsky, A. M. (2011). Models for moody s bank ratings. Frontiers in Finance and Economics, 1(8), 88-110. Retrieved from http://ssrn.com/abstract=2012447

Royston, P., \& Sauerbrei, W. (2009). Bootstrap assessment of the stability of multivariable models. The Stata Journal, 9(4), 547-570. Retrieved from http://ageconsearch.umn.edu/bitstream/143012/2/sjart_st0177.pdf

Salvador, C., De Guevara, J. F., \& Pastor, J. M. (2018). The adjustment of bank ratings in the financial crisis: International evidence. The North American Journal of Economics and Finance, 44, 289-313. https://doi.org/10.1016/j.najef.2018.01.001

Scott, L. J., \& Freese, J. (2006). Regression models for categorical dependent variables using stata. Texas, College Station: Stata Press.

Shen, C. H., Huang, Y. L., \& Hasan, I. (2012). Asymmetric benchmarking in bank credit rating. Journal of International Financial Markets, Institutions and Money, 22(1), 171-193. https://doi.org/10.1016/j.intfin.2011.08.004

Standard \& Poor's. (1998). Bank Financial Strength Key Factors. ARCHIVE | Criteria | Financial Institutions | Banks, Jun 24.

Standard \& Poor's. (2011a). Sovereign Government Rating Methodology And Assumptions. Criteria | Governments $\mid$ Sovereigns, June 30.

Standard \& Poor's. (2011b). Bank spreadsheet data definitions. Criteria Financial Institutions Banks, July 5.

Standard \& Poor's. (2011c). Banks: Rating Methodology and Assumptions. Criteria Financial Institutions Banks, November 9.

Standard \& Poor's. (2011d). Analytical Linkages Between Sovereign And Bank Ratings. Global Credit Portal | RatingsDirect, Dec. 6.

Standard \& Poor's. (2012). Sovereign Ratings and Country T\&C Assessments. Jan. 13. 
Teker, D., Pala, A., \& Kent, O. (2013). Determination of Sovereign Rating: Factor Based Ordered Probit Models for Panel Data Analysis Modelling Framework. International Journal of Economics and Financial Issues, 3(1), 122-132.

Williams, G., Alsakka, R., \& Gwilym, O. (2013). The impact of sovereign rating actions on bank ratings in emerging markets. Journal of Banking \& Finance, 37, 563-577.

Wojewodzki, M., \& Boateng, A. (2021). Banks' Capital, Credit Ratings, and Asymmetric Information: International Evidence. World Finance Conference, Paper Working. Retrieved from https://www.world-finance-conference.com/papers_wfc/05cea47bb88460b3bc943636b33a25ff.pdf

\section{Notes}

Note 1. CAMELS is the acronyms of «Capital, Assets, Management, Earnings, Liquidity and Sensitivity to market risk».

Note 2. Following this declaration, we can expect a pronounced importance of the sovereign rating for DdC affected by the debt crisis in 2012 .

Note 3. The averages of the financial ratios of $\mathrm{N}-3, \mathrm{~N}-2$ and $\mathrm{N}-1$ are used as independent variables to explain the $\mathrm{N}$-year ratings.

Note 4. S\&P's (2011b) states that it makes analytical adjustments to the amounts reported in the financial statements and regulatory filings of the rated entities. These adjustments, under the S\&P's termes, are made to generate measures that are more meaningful reflections of the economic reality of financial risks and to level the ratio differences and facilitate comparison between institutions and periods, which improves the analytical relevance and consistency of the financial ratios used in the credit analysis.

Note 5. We calculated the means, standard deviations, minimums, and maximums of the variables by year of rating. But we have not carried over the corresponding table. We used the stata 12 for all our data treatments.

Note 6. We calculated the correlations between the variables using the Pearson coefficient for CAMEL variables (Pearson coefficients less than 64.37\%), Khi-2 test for dummy variables (OC and ACT) and analysis of variance (ANOVA) for mixed variables. We also compared the means or proportions of the variables by year of rating using Student's test. But we have not carried over the corresponding tables.

Note 7. Bissoondoyal-Bheenick and Treepongkaruna (2011) found that the studies on grades and classes give different results. We used the stata 12 for all our data treatments.

Note 8 . The VIF measure the multicollinearity between the explanatory variables. VIF=1/(1-R2i) with R2i is the coefficient of determination of the regression of the variable $i$ with the other explanatory variables. A VIF superior to five indicates a strong multicollinearity.

Note 9. The BIF is a way of assessing the degree of stability of the model. The instability of the model occurs when the selected predictors are sensitive to a small change in data (Royston and Sauerbrei, 2009). The BIF is the frequency of the variables used in each sample and could be interpreted as a criterion of the importance of a variable. A variable, which is weakly correlated with others and significant in the complete model must be selected in half of the bootstrap (BIF greater than or equal to 50\%) samples. With the 'p-values' lower, the BIF increases to $100 \%$.

Note 10. High Chi2 and low "p-value" indicate the presence of proportional odds approach.

Note 11. High Chi2 and low "p-value" indicate the presence of heteroskedasticity.

Note 12. For the equations from (2) to (4), we reported only the explanatory powers of regressions.

Note 13. We don't report the table of Bootstrapping regressions.

\section{Copyrights}

Copyright for this article is retained by the author(s), with first publication rights granted to the journal.

This is an open-access article distributed under the terms and conditions of the Creative Commons Attribution license (http://creativecommons.org/licenses/by/4.0/). 